\title{
Effect of nifedipine on bronchoconstriction induced by inhalation of cold air
}

\author{
ALLAN F HENDERSON, RICHARD W HEATON, JOHN F COSTELLO \\ From the Chest Unit, King's College Hospital Medical School, London
}

\begin{abstract}
The effect of nifedipine (20 mg sublingually) on the bronchial response to cold air was studied in eight asthmatic patients and eight normal subjects. Eucapnic hyperventilation with dry subfreezing air was performed for three minutes by each subject, with a minute volume of $30 \times$ $\mathrm{FEV}_{1}$ for normal subjects and half that for the asthmatics. In the normal subjects there was no difference in the falls in the one-second forced expiratory volume $\left(F E V_{1}\right)$ and specific airways conductance (sGaw) produced by cold air inhalation on the days when they were pretreated with placebo and with nifedipine. In asthmatic patients, however, significant protection with nifedipine was demonstrated. The maximum recorded fall in $\mathrm{FEV}_{1}$ was reduced from $13 \% \pm 2 \%$ (SE) to $4 \% \pm 2 \%(\mathrm{p}<0.005)$ and the maximum fall in sGaw from $35 \% \pm 5 \%$ to $17 \% \pm 4 \%$ $(p<0.002)$. The possible causes of this difference are discussed. It is suggested that these results present further evidence for a different mechanism of response to cold air in asthmatic and normal subjects.
\end{abstract}

Respiratory heat loss is considered by many investigators to be the fundamental stimulus through which bronchoconstriction is produced in individuals with exercise-induced asthma. Furthermore, it has been shown that whereas only a proportion of asthmatics complain of exercise-induced wheezing all asthmatics develop bronchoconstriction when respiratory heat loss is produced by eucapnic hyperventilation of dry, subfreezing air. ${ }^{12}$ If the heat loss is increased beyond that necessary to produce bronchoconstriction in asthmatic subjects (by lowering the temperature of the air or increasing rates of ventilation) normal subjects also react with a bronchoconstrictor response. ${ }^{3}$ In the previous paper in this issue ${ }^{4}$ we have shown that asthmatic and normal subjects differ not only in the magnitude of their response but also in the underlying mechanism.

Nifedipine is a calcium-channel-blocking agent which has been shown to inhibit exercise-induced asthma, ${ }^{5-7}$ antigen-induced bronchoconstriction, ${ }^{8}$ and bronchospasm produced by inhalation of histamine and methacholine..$^{10}$ In this study we have investigated the effect of nifedipine on the bronchial response to cold air in normal and asthmatic subjects.

Address for reprint requests: Dr AF Henderson, Chest Unit, King's College Hospital Medical School, London SE5 8RX.

Accepted 2 February 1983

\section{Methods}

Two groups of subjects were studied. Eight asthmatic patients (three men and five women: mean age 28.4 years, range 24-35) were recruited from the asthma clinic at King's College Hospital. All had documented reversible airways obstruction of at least $15 \%$ and were able to discontinue all medication for at least 12 hours before each study period. None was having regular treatment with oral corticosteroids or sodium cromoglycate. Baseline values of the forced expiratory volume in one second $\left(F_{1} V_{1}\right)$ were within $25 \%$ of the predicted value and varied by less than $10 \%$ between the study days. Seven of the subjects were atopic as judged by positive responses to common allergens in skinprick tests; one was non-atopic. Five of the eight subjects had symptoms of exercise-induced wheezing. Eight normal subjects (six men and two women: mean age $27 \cdot 3$ years, range $21-34$ ) were recruited from hospital staff. One subject was atopic but none had a history of asthma and lung function was within the predicted range.

All subjects gave their informed consent to the study.

Dry air at subfreezing temperatures was generated with the apparatus previously described. ${ }^{4}$ There were two study sessions for each subject, performed on different days at the same time of day. At each 512 
session baseline readings of $\mathrm{FEV}_{1}$ were made with a Vitalograph spirometer and specific airways conductance (sGaw) with a Collins constant-volume whole-body plethysmograph. Values of sGaw were taken as the mean of five readings at each time interval. The subjects then received either placebo or nifedipine $20 \mathrm{mg}$ in randomised, double-blind order. Placebo capsules were identical to the nifedipine capsules in appearance and contained an identical peppermint-tasting liquid. Subjects were instructed to bite through the capsules and to hold the liquid contents in the mouth for one minute to allow sublingual absorption of the drug before swallowing the residue. With this method of absorption serum concentrations reach a peak after 30 minutes. ${ }^{11}$

Repeat determinations of $\mathrm{FEV}_{1}$ and sGaw were made at 25 minutes and a cold air challenge was administered at 30 minutes. In all cases the challenge lasted for three minutes. Normal subjects were required to breathe at about $80 \%$ of their maximal breathing capacity, calculated as $30 \times \mathrm{FEV}_{\text {, }}$ per minute $;^{12}$ and asthmatics, who have been shown to be more sensitive to the stimulus, ${ }^{34}$ at half this rate. With these levels of ventilation our apparatus generates temperatures of inspired air of $-22^{\circ}$ to $-25^{\circ}$ for asthmatic subjects and $-18^{\circ}$ to $-20^{\circ}$ at the higher flow rates of normal subjects. $\mathrm{FEV}_{1}$ and
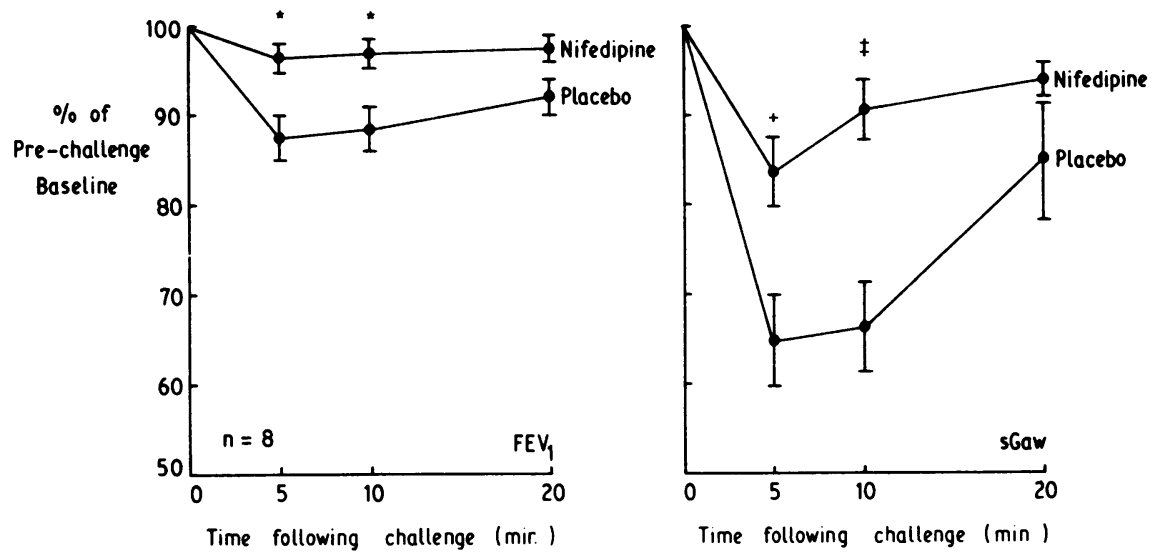

Fig 1 Effect of nifedipine on the bronchial response to cold air in asthmatic subjects. Changes in FEV, (left) and sGaw (right) are expressed as percentages of the prechallenge values and plotted against time after challenge. Nifedipine provided significant protection five and 10 minutes after challenge. By 20 minutes the effect of the cold air had subsided. ${ }^{*} p<0.005$; $\dagger p<0.02 ; \neq p<0.002$.
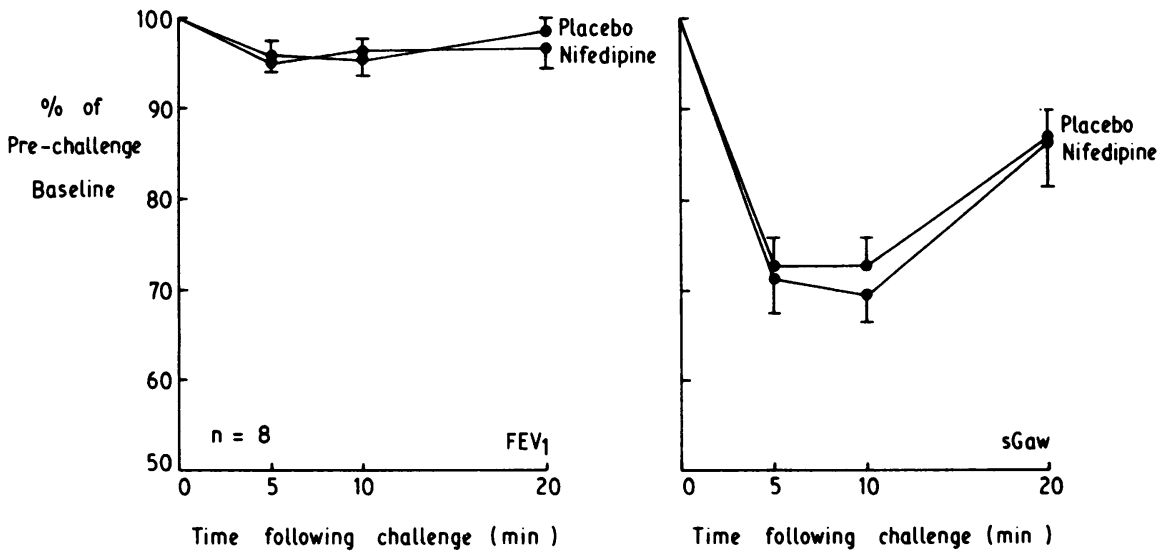

Fig 2 Effect of nifedipine on the bronchial response to cold air in normal subjects (indices as in fig 1). There is no significant difference at any point. 
sGaw were determined five, 10 , and 20 minutes after the end of the challenge.

Any bronchospasm persisting at the end of each session was alleviated by inhaled salbutamol.

The results in each group were analysed by Student's $t$ test for paired data.

\section{Results}

In agreement with the results of previous studies, ${ }^{5-9}$ nifedipine $20 \mathrm{mg}$, given sublingually, produced no significant change in resting airway function. Flushing and headache were noticed by both groups of subjects, but there were individual variations in severity.

Figure 1 shows the effect of nifedipine on the response to cold air in asthmatic subjects. Pretreatment with nifedipine reduced the maximum recorded fall in $\mathrm{FEV}_{1}$ from $13 \% \pm 2 \%$ (SE) to $4 \% \pm 2 \%(\mathrm{p}<0.005)$ and in sGaw from $35 \% \pm 5 \%$ (SE) to $17 \% \pm 4 \%(\mathrm{p}<0.002)$. All subjects were protected by nifedipine. There was no correlation between the amount of protection it gave and the subject's baseline FEV percentage of predicted normal). The one nonatopic asthmatic subject was protected by nifedipine to a similar extent to the rest of the group. In contrast the normal subjects were not protected by nifedipine and their falls in $\mathrm{FEV}_{1}$ and sGaw were identical on the two study days (fig 2 ).

\section{Discussion}

Nifedipine gave significant protection against the effects of cold air inhalation in our asthmatic subjects but not in normal individuals. Several explanations for this must be considered.

In the previous paper we concluded that asthmatic subjects differ from normal individuals not only in their sensitivity to cold air and the magnitude of their response but also in the underlying mechanism of the response. ${ }^{4}$ Normal subjects were completely protected by low doses of the cholinergic-blocking drug ipratropium; whereas asthmatics, while also deriving protection from ipraptropium, exhibited an extra component in their response that was inhibited by cromoglycate. These results suggest that the response in normal individuals is mediated via a vagal reflex alone, while the response in asthmatics is partly due to the action of locally released mediators.

Nifedipine, a pyridine derivative, exerts its effect by blocking the entry of calcium ions into cells. ${ }^{13}$ Calcium ion influx is implicated in two processes important in asthma-contraction of bronchial smooth muscle ${ }^{14}$ is and degranulation of mast cells with subsequent release of mediators. ${ }^{16}$ Possibly therefore nifedipine has a greater inhibitory effect on mast cell degranulation than on smooth muscle contraction. There is some support for a mast-cell stabilising effect of nifedipine from the findings of Cerrina et $a l^{17}$ that nifedipine inhibited the antiIgE-induced release of slow-reacting substance of anaphylaxis (SRS-A) from human lung fragments. These authors did not, however, observe inhibition of histamine release by nifedipine in their experiments, and Butchers et al were unable to show reduction of histamine release from sensitised lung fragments after antigen challenge. ${ }^{18}$ In studies of the effect of nifedipine on exercise-induced asthma Barnes et al reported abolition of the increase in plasma histamine after exercise. ${ }^{6}$ Our own studies of the effect of nifedipine on contraction of passively sensitised strips of human bronchial muscle induced by antigen challenge ${ }^{8}$ suggest that the main effect of nifedipine is to impair bronchial smooth muscle contractility rather than to stabilise mast cells. We believe therefore that the observed differences between normal and asthmatic subjects cannot be explained purely in terms of an effect of nifedipine on release of mediators from mast cells.

Free calcium ions in the smooth muscle cytoplasm trigger the contractile response and modulate muscle tone. ${ }^{19}$ Increase in cytoplasmic calcium may occur as a result of influx of extracellular stores. Acetylcholine-induced contractions of bovine trachealis muscle are relatively resistant to reduced extracellular calcium ion concentrations, ${ }^{14}$ which suggests that intracellular calcium depots are more important. The studies of Farley and Miles show a mixed dependence on intracellular and extracellular calcium ion sources in contraction of canine trachealis muscle induced by acetylcholine. ${ }^{20}$ Our own in vitro studies show a relatively small inhibitory effect of nifedipine on acetylcholine-induced contractions of human bronchial muscle, ${ }^{8}$ particularly with concentrations of nifedipine likely to be encountered in vivo. The presumed vagally mediated reflex response to cold air seen in normal subjects might therefore be expected to show little modification by an agent which has little effect on cholinergic responses and this is seen to be the case.

In asthmatic subjects the reponse to cold air is probably at least partly brought about via the action of locally released mediators from mast cells. These would include histamine, prostaglandins, and leukotrienes. The coupling of the action of these to the mechanical response of the bronchial smooth muscle cell may be more dependent on extracellular calcium ion sources and be subject to modification by nifedipine.

Finally, the pharmacology of asthmatic bronchial 
smooth muscle may differ from that of normal subjects. The fundamental cause of bronchial hyperreactivity is not known, ${ }^{21}$ but a difference at the level of smooth muscle is a possibility.

\section{References}

${ }^{1}$ Deal EC jun, McFadden ER jun, Ingram RH, Strauss $\mathrm{RH}$, Jaeger JJ. Role of respiratory heat exchange in production of exercise induced asthma.J Appl Physiol 1979;46:467-75.

${ }^{2}$ Deal EC jun, McFadden ER jun, Ingram RH jun, Jaeger $J J$. Hyperpnea and heat flux: Initial reaction sequence in exercise-induced asthma. $J$ Appl Physiol 1979;46:476-83.

${ }^{3}$ O'Cain CF, Dowling NB, Slutsky AS, et al. Airway effects of respiratory heat loss in normal subjects. $J$ Appl Physiol 1980;47:875-80.

${ }^{4}$ Heaton RW, Henderson AF, Gray BJ, Costello JF. The bronchial response to cold air challenge: evidence for a different mechanism in normal and asthmatic subjects. Thorax 1983;83:506-11.

s Cerrina J, Denjean A, Alexandre G, Lockhart A, Duroux P. Inhibition of exercise-induced asthma by a calcium antagonist, nifedipine. Am Rev Respir Dis 1981;123:156-60.

- Barnes PJ, Wilson NM, Brown MJ. A calcium antagonist, nifedipine, modifies exercise-induced asthma. Thorax 1981;36:726-30.

${ }^{7}$ Patel KR. The effect of calcium antagonist, nifedipine in exercise-induced asthma. Clin Allergy 1981;11:42932.

${ }^{8}$ Henderson AF, Heaton RW, Dunlop LS, Costello JF. Effects of nifedipine on antigen-induced bronchoconstriction. Thorax 1982;37:387 (abstract).

9 Williams DO, Barnes PJ, Vickers HP, Rudolf M. Effect of nifedipine on bronchomotor tone and histamine reactivity in asthma. $\mathrm{Br}$ Med $J$ 1981;283:348.

${ }^{10}$ Malik S, O' Reilly J, Sudlow MF. Effects of sublingual nifedipine on inhaled histamine and methacholineinduced bronchoconstriction in atopic subjects. Thorax 1982;37:230 (abstract).

"Ramsch K. Zur Pharmakokinetik von Nifedipin. Schwerpunkt Medizin 1981;4:4.

12 Gandevia B, Hugh-Jones P. Terminology for measurements of ventilatory capacity. Thorax 1957;12:290-3.

${ }^{13}$ Fleckenstein A. Adalat, a powerful Ca-antagonistic drug. In: Lockner W, Brausch W, Kroneberg G, eds. Second Adalat symposium: New therapy of ischaemic heart disease. New York: Springer-Verlag, 1975:5665.

${ }^{14}$ Kirkpatrick CT. Excitation and contraction in bovine tracheal smooth muscle. J Physiol 1975;244:263-81.

${ }^{15}$ Coburn RF. The airway smooth muscle cell. Fed Proc 1977;36:2692-6.

${ }^{16}$ Foreman JC, Hallett MB, Mongar JC. The relationship between histamine secretion and ${ }^{45}$ calcium uptake by mast cells. J Physiol 1977;271:193-214.

${ }^{17}$ Cerrina J, Hadji L, Marche E, Duroux P, Benveniste J. Effect of $\mathrm{Ca}^{2+}$ antagonist nifedipine on histamine and SRS release from human lung tissue. Am Rev Respir Dis 1982;125, suppl:64.

${ }^{18}$ Butchers PR, Skidmore IF, Vardey CJ, Wheeldon A. Calcium antagonists in exercise-induced asthma. $\mathrm{Br}$ Med J 1981;282:1792.

19 Adelstein RS, Hathaway DR. Role of calcium and cyclic adenosine $3^{\prime}: 5^{\prime}$ monophosphate in regulatory smooth muscle contraction. Am J Cardiol 1979;44:783.

${ }^{20}$ Farley JM, Miles PR. The sources of calcium for acetylocholine-induced contractions of dog tracheal smooth muscle. J Pharmacol Exp Therap 1978;207:340-6.

21 Tattersfield AE. Measurement of bronchial reactivity: a question of interpretation. Thorax 1981;36:561-5. 